DEMOGRAPHIC RESEARCH

VOLUME 33, ARTICLE 2, PAGES 31-64

PUBLISHED 3 JULY 2015

http://www.demographic-research.org/Volumes/Vol33/2/

DOI: 10.4054/DemRes.2015.33.2

Research Article

\title{
Marriage and divorce of immigrants and descendants of immigrants in Sweden
}

\section{Gunnar Andersson}

Ognjen Obućina

\section{Kirk Scott}

This publication is part of the Special Collection on "Partnership dynamics among immigrants and their descendants in Europe,” organized by Guest Editors Hill Kulu and Tina Hannemann.

(C2015 Gunnar Andersson, Ognjen Obućina \& Kirk Scott.

This open-access work is published under the terms of the Creative Commons Attribution NonCommercial License 2.0 Germany, which permits use, reproduction \& distribution in any medium for non-commercial purposes, provided the original author(s) and source are given credit.

See http:// creativecommons.org/licenses/by-nc/2.0/de/ 


\section{Table of Contents}

1 Introduction 32

$2 \quad$ Marriage formation and divorce in Sweden 32

$3 \quad$ Immigrants in Sweden 33

$4 \quad$ Theoretical considerations and previous research on marriage and 35 divorce of immigrants

4.1 Marriage formation among immigrants 36

4.2 Previous research on divorce among immigrants 38

$\begin{array}{lll}4.3 & \text { Re-marriage among immigrants } & 39\end{array}$

4.4 Hypotheses 40

$\begin{array}{lll}5 & \text { Data and methods } & 40\end{array}$

6 Results I: First marriage formation of immigrants in Sweden 42

$7 \quad$ Results II: Divorce risks of immigrants in Sweden 46

8 Results III: Re-marriage propensities of immigrants in Sweden 49

9 Discussion $\quad 52$

10 Acknowledgements 56

$\begin{array}{ll}\text { References } & 57\end{array}$ 


\title{
Marriage and divorce of immigrants and descendants of immigrants in Sweden
}

\author{
Gunnar Andersson ${ }^{1}$ \\ Ognjen Obućina ${ }^{2}$ \\ Kirk Scott ${ }^{3}$
}

\begin{abstract}
BACKGROUND

Immigrants and their second-generation descendants make up more than a quarter of the current Swedish population. Their nuptiality patterns can be viewed as crucial indicators of their integration into Swedish society.
\end{abstract}

\section{OBJECTIVES}

This study provides data on levels of and patterns in marriage formation, divorce, and re-marriage of people in Sweden, by country of origin.

\section{METHODS}

The study is based on analyses of longitudinal register data that cover all residents born in 1951 and later who ever lived in Sweden during 1983-2007. Kaplan-Meier survivor functions demonstrate levels in nuptiality; multivariate event-history analyses demonstrate relative risks of marriage formation and divorce, by country group of origin.

\section{RESULTS}

We find evidence of variation among immigrant groups and between migrants and Swedish-born people in marriage and divorce patterns. A few groups of migrants have relatively high churning rates in family dynamics, with high levels of marriage formation, divorce, and re-marriage.

\section{CONCLUSIONS}

Many factors relate to the nuptiality behavior of immigrants in Sweden. Differences in family systems seem to have some influence on behavior in the contemporary Swedish context. Other factors relate to the migration process itself and to the selectivity of migrants to Sweden.

${ }^{1}$ Stockholm University Demography Unit, Stockholm, Sweden. E-Mail: gunnar.andersson@sociology.su.se.

${ }^{2}$ Stockholm University Demography Unit, Stockholm, Sweden.

${ }^{3}$ Centre for Economic Demography, Lund, Sweden. 


\section{Introduction}

Sweden is often seen as situated at an advanced stage of the so-called Second Demographic Transition of family change (van de Kaa 1987). It also has relatively high levels of immigration. Further, it possesses high-quality demographic data, which makes it possible to study some of these developments. In the present study we take advantage of these opportunities to study patterns in marriage formation and marriage dissolution of immigrants and descendants of immigrants in Sweden. Our study is based on analyses of longitudinal register data that cover the resident population in Sweden during 1983-2007. In contrast to census data, which lack longitudinal information on civil status histories, and survey data, which most often contain too few immigrants to allow for group-specific analyses, our data allow for very detailed and accurate analyses of the nuptiality patterns of key categories of immigrants. Our study focuses on women: it covers their patterns of marriage formation and divorce (the registers provide less useful information on non-marital cohabitation). We study female immigrants who arrived in Sweden as unmarried persons, and follow their subsequent civil-status careers while living in Sweden. We also cover the nuptiality patterns of the daughters of immigrants in Sweden. By means of longitudinal analyses of the marriage formation and divorce behavior of immigrant and non-migrant women, we demonstrate how patterns in nuptiality differ by migration status and country of origin and how they are modified by women's socio-demographic characteristics. Our study adds insight into patterns of family demographic integration of migrants to Sweden. We address issues related to the disruption and adaptation of the family-demographic behavior of migrants and how the selectivity of migrants may contribute to differences in behavior in the Swedish context. We aim at contributing to a better understanding of the role of factors related to differences in family systems and the institutional setting of Sweden in shaping the family-demographic behavior of immigrants.

\section{Marriage formation and divorce in Sweden}

During the 1960s and 1970s Sweden was renowned for its decline in marriage formation rates (Bernhardt and Hoem 1985; Andersson 1998; Statistics Sweden 2014). The country was then a forerunner in the establishment of non-marital cohabitation as an alternative to marriage (Trost 1979) and in the evolution of the so-called Second Demographic Transition of Europe (van de Kaa 1987; see also Sardon 1986). In contrast to this trend, a spectacular but temporary rise in marriage propensities occurred in 1989 in response to new rules concerning the (non-)eligibility for a widow's pension (Hoem 1991). In more recent years we find a more long-lasting trend reversal in 
marriage formation propensities. Ever since the end of the 1990s, marriage rates in Sweden have increased (Ohlsson-Wijk 2011). Re-marriage propensities have increased as well (Andersson and Kolk 2011), emphasizing the recent development of the increasing popularity of marriage. Practically all marriages are preceded by periods of pre-marital cohabitation and the majority of marriages are preceded by premarital childbearing as well. In a European comparison, Swedish women and men form a union at relatively early ages but are relatively late in getting married (Andersson and Philipov 2002).

In terms of marital dissolution, Sweden is a country where divorce is easy to achieve; legislation that included no-fault grounds for divorce was introduced in 1915 (Sandström 2011). In 1974 the divorce legislation was liberalized further, which resulted in a pronounced increase in divorce risk levels (Andersson 1995, 1997). The trend of increasing divorce risk became visible earlier in Sweden than in other countries in Europe. Swedish divorce risks continued to increase at a moderate pace during the 1980s and 1990s. During this period, divorce was more common than in most other European countries, but less frequent than in the U.S. (Andersson 2002; Andersson and Philipov 2002). However, since the turn of the century Swedish divorce risks have leveled off (Andersson and Kolk 2011).

In Sweden, a person's marital status brings relatively few benefits in terms of social rights. For example, since 1971 taxation is based on spouses' own individual earnings and most social benefits are based on a person's own economic status, regardless of his or her marital or family status. After divorce, joint custody of children is common, but otherwise spouses no longer have to interact with each other. The relatively weak instrumental role of marriage may mean that there is more scope for various ideational and symbolic factors related to marriage in creating differentials between population sub-groups in their nuptial behaviors (Ohlsson-Wijk 2011, 2014, 2015). In the case of international migrants, factors related to family systems in the migrants' countries of origin may come into play.

\section{Immigrants in Sweden}

During the last century, Sweden evolved from a country with a distinctly homogenous population into a country with a much more mixed population in terms of national origins (Statistics Sweden 2004, 2010). In 2013 immigrants constituted some 16\% of the population; another $12 \%$ were Swedish-born descendants of immigrants with at least one parent born abroad (www.scb.se). Immigrants to Sweden come from a wide variety of countries, with very different family-demographic and social contexts. In our study we group them into the following country groups of origin. 
Immigrants from Finland still constitute the largest single foreign-born group in Sweden. Due to a shared national history up to the early 19th century and visible economic differentials between Finland and Sweden until the 1980s, labor migration from Finland to Sweden has been substantial. Other Nordic immigrants mainly comprise Danes and Norwegians but also a few Icelanders. As with the Finns, geographic proximity, shared culture, and the existence of a free Nordic labor market have helped ease migration as well as integration into Swedish society.

Immigrants from the Baltic countries mainly comprise pre- and post-Soviet migrants from Estonia. Polish immigrants in Sweden arrived for a variety of reasons. Some came as refugees from the previous communist regime; others arrived as spouses to Swedish men. Migrants from the rest of Eastern Europe include migrants who left the region during communism, mainly from Hungary, as well as post-communist migrants from, for example, Bulgaria and Romania. We include the post-Soviet states to cover migrants from post-communist Russia and other non-Baltic post-Soviet countries; migrants from Western Europe and from Southern Europe stem from a wide variety of countries in these regions. Immigrants from the former Yugoslavia come from all parts of the former Yugoslav state. They are split mainly between labor migrants arriving during the 1960s (mostly Serbs and Croats) and refugee migrants arriving in conjunction with the Balkan wars of the 1990s, most of them from Bosnia.

Turkey has a varied history of migration to Sweden. During the 1960s, Turks arrived as labor migrants, but later there was a shift in character towards refugee immigration, largely dominated by ethnic Kurds. Many migrants from Turkey belong to its Syriac minority. Most Iranian immigrants to Sweden came as refugees during the 1980s. Iranians then proceeded to become one of Sweden's largest immigrant nationalities. Immigrants from Middle East Arab countries include a large number of Iraqi immigrants. Most of them arrived in the aftermath of the 2003 US invasion of Iraq. In more recent years, Syria has become the prime source of refugee migration from this region.

Immigrants from Africa are divided into those coming from North Africa and those from Sub-Saharan Africa. Migrants from the Horn of Africa are a group large enough to constitute a category of its own. Somalis constitute more than half of this group; the rest are Eritreans and Ethiopians. Migrants from non-European Anglo-Saxon countries are joined into one single category. Immigrants from Central and South America include a large number of Chilean refugees and their family members. Migrants from South-East Asia mainly comprise ethnic-Chinese refugees from Vietnam and, more recently, immigrants from Thailand, who often have moved to Sweden as spouses to Swedish men. East Asia and South Asia are defined as two separate regions of origin. 


\section{Theoretical considerations and previous research on marriage and divorce of immigrants}

Our research is motivated by the possibility of observing similarities and differences in partnership dynamics between natives and immigrants as well as across immigrant groups. Similarities in patterns may be taken as evidence of adaptation of behaviors to those prevailing in the Swedish context. Differences in patterns between migrant and Swedish-born women, which may remain even after controlling for observable sociodemographic characteristics, may reflect the impact of circumstances related to the migration process. Differences in patterns across migrant groups may reflect the impact on nuptiality of differences in family systems prevailing in the migrants' countries of origin.

Sweden's immigrant population is fairly heterogeneous with respect to norms and value systems in their countries of origin: immigrants come from countries and regions of the world with widely different family systems (Goode 1963, 1993). In line with the socialization hypothesis (Kulu and González-Ferrer 2014), this variety constitutes one of the key mechanisms creating differences in behavior in Sweden. Moreover, factors related to culture are portable from one country to another and can be transmitted to younger generations even outside the original geographical context (Furtado, Marcén, and Sevilla 2013). This makes it relevant for us to also consider Swedish-born individuals of foreign parental origin as separate categories in our analyses. In the context of Sweden, where few legal obligations and benefits are attached to marriage, cultural factors may manifest more strongly in partnership dynamics than in a context where a person's civil status is a much stronger determinant of his or her social and legal rights. Nevertheless, interpreting all differences in behavior as merely the reflection of factors related to culture and differences in family systems would be simplistic. For instance, it is likely that the very act of migration constitutes an own source of differentiation in partnership dynamics. Migration to another country often involves elements of stress: it may create the seeds for marital instability and may also initially hamper marriage formation because the marriage market is new and unfamiliar. On the other hand, if it is perceived to offer a more secure status in a new and sometimes insecure context, marriage may be found to be more attractive. Marriage and family reunification is a common motive for migration (Statistics Sweden 2008).

Further, immigrants are never likely to represent a random sample of their populations at origin (Chiswick 1978; McDonald and Kennedy 2004). Selection into migration varies considerably by type of migration, migration intensity, and country of origin: the salience of factors related to migration and country of origin in explaining partnership dynamics will depend on how selective migration flows are. To the best of our knowledge there is no empirical research that specifically addresses the issue of 
how selection into migration affects marriage formation and divorce. We are unable to estimate the impact of selection with the data available to us, but it is always necessary to consider the possible role of selection when interpreting the results of analyses like ours. For instance, Iranian immigrants in Sweden largely stem from urban areas and are often considered more secular than the population in general in their country of origin (Graham and Khosravi 1997; Kelly 2013). These characteristics may be related to marriage propensities and divorce risks. By contrast, the mechanisms of migration from neighboring Turkey to Sweden have been very different and produced an overrepresentation of individuals originating from rural areas.

While factors related to characteristics of family systems in migrants' countries of origin and different aspects of selection into migration are likely to produce inter-group differences in partnership dynamics, the processes of adaptation and integration into the social fabric of migrants' countries of destination may work in the opposite direction (Andersson 2004a; Kulu 2006; Kulu and González-Ferrer 2014). Marriage formation and marriage dissolution among immigrants may increasingly resemble that of natives due to exposure to the norms and values prevailing in the destination country. Moreover, in Sweden the institutional context may encourage the equalization of family-demographic behaviors. Swedish social policies are explicitly geared towards promoting social equality and immigrants are granted the same social rights as natives. The equal access of immigrants to formal social rights in the universalistic welfare state of Sweden may contribute to producing similarities in demographic behavior. Previous research on fertility and parity progressions of immigrants in Sweden has revealed striking similarities rather than differences in childbearing behavior between foreignand Swedish-born people and between different groups of immigrants (Andersson 2004a, Andersson and Scott 2005, 2007).

\subsection{Marriage formation among immigrants}

One of the ways in which values related to family formation can shape group-specific marriage risks is through their influence on the timing of union formation. Huschek, Liefbroer, and de Valk (2010) analyze the timing of first union formation among the descendants of Turkish immigrants in urban areas in Sweden and six other European countries. One of their main findings is that growing up in what the authors label a "traditional" Turkish family is associated with an earlier entry into first union. However, cultural and ideational factors are also at work when it comes to the acceptance of cohabitation as a temporary or durable alternative to marriage, which may also influence the risk of marriage formation. In Sweden, cohabitation is a more common living arrangement than in most other countries (Duvander 1999; Andersson 
and Philipov 2002; Andersson 2004b). This is primarily dictated by a very high acceptance of cohabitation among Swedish-born natives. According to Dribe and Lundh (2012), around one half of natives in endogamous unions have their first child in non-marital cohabitation, while the corresponding share among endogamous immigrant unions is only $8 \%$. Bernhardt et al. (2007) study the transition to adulthood among children of Turkish and Polish immigrants in Sweden and find that these groups, the former in particular, differ from natives in terms of the propensity for non-marital cohabitation. Given these findings and considering that many immigrants originate from countries where marriage has a more dominant role in partnership dynamics than in Sweden, it should be expected that the foreign-born on average are relatively more likely to enter formal marriage. The findings by Ohlsson-Wijk (2011) indicate that this indeed is the case. Her study shows that non-Nordic European and non-European women, particularly those younger than 30, have a higher risk of marriage formation than Swedish-born women. However, her classification of immigrant groups was far less detailed than ours as the native-immigrant differentials in family behavior were not the primary focus of her study. Nekby (2012) studied broad country groups of descendants of immigrants in Sweden and found that, with the exception of those of Nordic origin, they are often more likely than natives to be married at young ages. The propensity to be married at young age is especially pronounced among the descendants of immigrants from Asia.

Evidently, the migration event itself may have a role to play in shaping marriage propensities. Marriage-related migration by definition increases the marriage risk for immigrants - if marriage formation occurs after the migration event rather than the other way round. That is, for a non-negligible share of immigrants the decision to leave the country of origin was motivated by the intention to marry a person living in Sweden. Marrying a partner from the country of origin is not uncommon among immigrants in Sweden and elsewhere in Europe (Charsley 2005; Eeckhaut et al. 2011; van Kerckem et al. 2013; Obućina 2014). To illustrate, the most common reason for granting residence permits in Sweden is family reunification: in the period 2002-2006 three out of four of these permits were issued to "newly formed marriages" (Parusel 2009). Although an increasing number of marriage migrants arrive in Sweden to marry a native Swede (Niedomysl, Östh, and Van Ham 2010; Haandrikman 2014), it is more common to marry another migrant (Dribe and Lundh 2011). By contrast, if not motivated by marriage, the act of migration may instead postpone the entry into marriage. As discussed in Sobotka (2008) and Adsera and Ferrer (2014), international migration is a stressful event and in some cases also entails entering a less familiar marriage market where a new language is spoken. There is no empirical research on this issue for Sweden, but we cannot discard the possibility that this mechanism contributes to depressing the marriage formation rates of adult unmarried immigrants in Sweden. 


\subsection{Previous research on divorce among immigrants}

Based on Swedish register data for 2005, Nekby (2012) studies seven broad categories of immigrants in Sweden and finds that the probability of being divorced is generally higher among the foreign-born than among native Swedes. The propensity to be divorced was highest among Asian and South American immigrants and lowest among Western European immigrants. Statistics Sweden (2012) report higher divorce risks on average among immigrants than among native Swedes. Nekby (2012) further finds that the descendants of immigrants are more likely to be divorced than are natives, but this difference was less pronounced. Previous literature has dealt with the possible link between culture and divorce (e.g., Furtado, Marcén, and Sevilla 2013) and cultural factors remain a strong candidate for explaining group-specific differentials in divorce in our study as well. For instance, one of the findings that emerge from the study by Dribe and Lundh (2012) on intermarriage in Sweden is that endogamous immigrant couples that originate from different value contexts also differ in their divorce risk.

However, there are good reasons to also consider other mechanisms when interpreting the results of our analyses. For example, homogamy theory predicts that a higher degree of dissimilarity in marital unions in terms of values and lifestyle is related to a higher divorce risk (Kalmijn, de Graaf, and Janssen 2005). This argument matters because some immigrant groups may be characterized by a substantial degree of intraethnic cultural heterogeneity, partly due to differences in length of exposure to the host society. Homogamy theory thus predicts elevated divorce risks for sociodemographically more heterogeneous immigrant couples and populations, even after controlling for partner's country of birth. For example, Lesthaeghe and Surkyn (1995) identify a considerable degree of heterogeneity and heteropraxis among Turkish and Moroccan immigrants in Belgium and argue that marriage migration is an important source of such intra-community cultural variation. Eeckhaut et al. (2011) study the same immigrant groups and find that marriage migration, as hypothesized, is associated with increased divorce risk. They also argue that, due to a higher degree of social support, divorce risks should be lower in more closely knit immigrant communities. A study by Milewski and Kulu (2014) on immigrants in Germany provides further support for this argument. For Sweden, Obućina (2014) finds that, within some immigrant groups, endogamous marriages in which one partner is a marriage migrant have higher divorce risks than immigrant endogamous marriages in which both partners were established in Sweden at the start of marriage.

Previous research also suggests that the interplay between migration and the exposure to different gender norms in society may matter for divorce risks among immigrants. The main argument is that men and women from countries with gender norms that are very different from those prevailing in Sweden may benefit from their migration to different extents. While for many men the move to Sweden entails 
downward social mobility and transition into unemployment, the increased opportunities for women may strengthen their resources in the family. According to Darvishpour (2002), post-migration change in power relations within the family is one of the principal sources of family instability for Iranian couples in Sweden. Although in our study we consider only the divorce risks of couples who have married in Sweden, we cannot discard the possibility that divergent attitudes of immigrant women and men towards prevalent gender norms in the host society can create family conflict for these couples (Lewin 2001).

\subsection{Re-marriage among immigrants}

In general, research on re-marriage among immigrants is very scarce. The prevailing view in the general literature on repartnering in developed countries is that the same factors that affect the entry into a first union also affect the entry into second and higher order unions, although the relative importance of some factors may change across union orders (Dewilde and Uunk 2008). Cohabitation is also a prominent alternative to marriage when repartnering, both in Sweden and elsewhere (Blanc 1987; de Graaf and Kalmijn 2003; Wu and Schimmele 2005). Therefore we may expect any (unobserved) country-specific levels of acceptance of cohabitation to produce native-immigrant differentials in remarriage as well. In addition, under certain conditions, marriage market constraints can matter more for second and higher order unions than for first marriages. For instance, the remarriage market may be quite thin for a foreign-born divorcee with a strong preference for cultural endogamy who originates from a country group with a low divorce propensity. In fact, re-marriage patterns may correlate more strongly with patterns in divorce risks than with those of first marriage formation. Goode $(1963,1993)$ claims that historical family systems that produce a lot of divorce also need to allow for high levels of remarriage. If factors related to family systems in the migrants' countries of origin matter in the Swedish context, then we may find evidence of high re-marriage rates for populations with high divorce risks. 


\subsection{Hypotheses}

Based on previous research and our theoretical considerations we may summarize our expectations by posing a few hypotheses on the nuptial behavior of immigrants in Sweden. As the previous section highlights, many factors are at play, but we could expect the following:

- Migration is a stressful life event, which causes disruption in marital life: this is likely to produce depressed marriage risks for unmarried migrants and elevated divorce risks for immigrants.

- The institutional context of Sweden encourages adaptation of immigrants' familydemographic behaviors towards the patterns of marriage and divorce that prevail in the native population. This leads to very small differences between groups in their nuptial behavior.

- Socialization to values related to family life continues to produce differences in behavior that can be linked to the working of the different family systems in migrants' countries of origin.

- Patterns of selective migration produce several expected and unexpected differences in immigrants' nuptial behavior.

In real life all factors are at play and it may be difficult to differentiate between the relative importance of each hypothesis.

\section{Data and methods}

As in all Swedish data, the definition of being an immigrant refers to a person's own country of birth: an individual born in a country other than Sweden and currently residing in Sweden is an immigrant. In addition, by means of recorded linkages between children and parents we are able to single out the descendants of migrants to Sweden: these are the resident offspring to one or two persons that were born in another country and that migrated to Sweden. Following the practice of much previous familydemographic research, we base our study on the nuptial behavior of women ${ }^{4}$. As a reference category we use Swedish-born women with two Swedish-born parents ('Swedish-born parents'). We further distinguish between Swedish-born women with two foreign-born parents ('Descendant of immigrants'; these are sometimes referred to in the literature as the "second generation" of immigrants), and Swedish-born women

\footnotetext{
${ }^{4}$ This may not be very good practice; in our case it serves the purpose of reducing an output of tabulations that is already quite extensive.
} 
with one foreign-born and one Swedish-born parent ('One parent Swedish-born'). The immigrants themselves are divided between women born abroad who arrived in Sweden during childhood ('Immigrated as child' while aged 15 years or less; these migrants are sometimes referred to in the literature as the "Generation 1.5"), and women born abroad who migrated to Sweden at adult ages ('Immigrated as adult'). The immigrants are also classified by their country groups of origin, as specified in our previous section.

Swedish register data provide full information on civil status changes of all persons with legal residence in the country. Linkages to other administrative registers provide background data on other socio-demographic characteristics of these individuals. There is no formal registration of non-marital cohabitation and the place of residence of an individual cannot be linked to single dwelling units of multi-family houses so it cannot be used to infer non-marital cohabitation. Our study thus is restricted to changes in formal civil status. For all unmarried migrants to Sweden and never-married residents in Sweden, we study i) the transition to first marriage formation. For those who married in Sweden, we study ii) the transition to first divorce. For those who subsequently experienced a divorce, we study iii) the transition to remarriage. All models are thus based on nested versions of the same initial study population. The longitudinal data are provided with the accuracy of a month. We present our results in terms of univariate Kaplan-Maier estimates of the fractions ever married at exact ages 25, 35, 45, and 55; the fractions divorced at durations 5, 10, and 15 years after first marriage formation; and the fractions re-married at durations 5 and 10 years after divorce. The analyses are based on women with a de jure residence in Sweden. In a next step, we carry out event-history analyses of the relative risks of first marriage formation, divorce, and re-marriage in Sweden, respectively. These are based on multivariate analyses where our main variable of interest is the country group of a woman's origin. For first-marriage formation we provide additional estimates with a more detailed specification of the descendants of immigrants to Sweden. The analyses are based on an unweighted 5\% sample of women with two Swedish-born parents and the entire resident population of immigrants and descendants of immigrants in Sweden (Table 1). We control for the following socio-demographic time-varying covariates: current age, educational attainment, and metropolitan/non-metropolitan residence (Stockholm, Göteborg, Malmö with suburbs vs. rest of Sweden). The divorce analyses additionally consider duration of marriage and husband's country of origin. The remarriage analyses consider duration since divorce. Observations are censored at any first emigration, death, or the end of last year of observation, whichever comes first. All analyses are based on women born in 1951 and later who ever lived in Sweden during 1983-2007. They cover patterns in nuptiality during 1983-2007. The analyses are carried out in STATA. 
Table 1: Study populations of first marriage formation, divorce, and remarriage in Sweden

\begin{tabular}{lcccc}
\hline & Unmarried & First married & Divorced & Remarried \\
\hline Swedish-born parents & 79,214 & 30,652 & 10,663 & 3,520 \\
Descendant of migrants & 83,284 & 28,345 & 9,292 & 3,193 \\
One parent Sw-born & 97,092 & 32,269 & 11,556 & 4,109 \\
Immigrant as child & 110,004 & 38,113 & 13,501 & 5,375 \\
Immigrant as adult & 149,722 & 52,766 & 18,724 & 6,219 \\
\hline $\mathrm{N}$ & 517,006 & 181,209 & 63,485 & 21,783 \\
\hline
\end{tabular}

Note: Swedish register data, authors' own calculations.

\section{Results I: First marriage formation of immigrants in Sweden}

Estimates of the cumulative fractions ever married at different ages (Table 2) show that about two thirds of Swedish-born women had been married at least once by age 55 . These statistics cover a synthetic cohort (1983-2007) with decreasing as well as increasing period trends in marriage formation (see Ohlsson-Wijk 2011); the relatively low levels of estimated ultimate marriage formation reflect the fact that the study period was marked by strong postponement in marriage formation ${ }^{5}$. The statistics on ultimate levels of marriage formation do not differ tremendously between native- and foreignborn women, but immigrants who arrived in Sweden during childhood marry somewhat earlier than others. Our estimates for specific country groups of immigrant women in the lower section of Table 2 cover all immigrants regardless of age at migration to Sweden. Differences between country groups are not extremely large: immigrants from Turkey, North Africa, and the Middle East have higher levels of ultimate marriage formation than women from other countries; a few country groups, including Turkey, the Arab Middle East, and the former Yugoslavia stand out with patterns of very early marriage formation. By contrast, immigrants from Western and Southern Europe display relatively low levels of marriage formation in Sweden.

\footnotetext{
${ }^{5}$ For women born during the 1950s, the ultimate level of ever-marriage reached about $80 \%$. For women born during the 1960s it was above 70\%. Later cohorts have not finished their nuptial careers but may reach similar or higher levels of marriage formation than those born during the 1960s (see also Ohlsson-Wijk 2011 and Statistics Sweden 2014).
} 
Table 2: Cumulative percentage married at ages 25, 35, 45, and 55, by country group of origin. Unmarried women in Sweden, 1983-2007

\begin{tabular}{lcccc}
\hline & $\mathbf{2 5}$ & $\mathbf{3 5}$ & $\mathbf{4 5}$ & $\mathbf{5 5}$ \\
\hline Swedish-born parents & 13 & 52 & 63 & 67 \\
Descendant of migrants & 19 & 53 & 63 & 67 \\
One parent Sw-born & 13 & 49 & 61 & 65 \\
Immigrant as child & 26 & 56 & 66 & 70 \\
Immigrant as adult & 12 & 45 & 59 & 64 \\
\hline Finland & 15 & 48 & 58 & 62 \\
Other Nordic & 10 & 43 & 58 & 64 \\
Former Yugoslavia & 32 & 59 & 68 & 71 \\
Poland & 14 & 48 & 60 & 65 \\
Western Europe & 7 & 39 & 53 & 60 \\
Southern Europe & 11 & 42 & 54 & 62 \\
Baltic & 9 & 40 & 54 & 65 \\
Eastern Europe & 16 & 49 & 62 & 66 \\
US/Aus/NZ/Can & 9 & 45 & 59 & 67 \\
Central/South America & 14 & 45 & 60 & 66 \\
Horn of Africa & 21 & 47 & 60 & 64 \\
Sub-Saharan Africa & 16 & 47 & 61 & 70 \\
North Africa & 23 & 57 & 73 & 80 \\
Arab Middle East & 41 & 69 & 80 & 84 \\
Iran & 16 & 53 & 69 & 75 \\
Turkey & 49 & 75 & 82 & 83 \\
East Asia & 8 & 47 & 66 & 73 \\
South-East Asia & 12 & 44 & 64 & 73 \\
South Asia & 12 & 44 & 64 & 67 \\
Post-Soviet States & & 61 & 70 \\
\hline & & & & \\
\hline
\end{tabular}

Note: Swedish register data, authors' own calculations.

The same patterns are reflected in the relative risks of first marriage formation presented in Tables $3 a-b$, where we are also able to control for the role of a few sociodemographic covariates. Table 3a presents the relative risks of marriage formation for our five aggregated categories of migration status: it confirms that immigrants who arrived in Sweden during childhood marry earlier than others, while adult migrants on average have somewhat depressed marriage formation intensities. Descendants of immigrants also have slightly elevated risks of marriage formation, but children with one foreign- and one Swedish-born parent have reduced marriage formation intensities. Table $3 \mathrm{~b}$ presents the relative risks of the same model when the immigrants are distributed over much finer country groups of origin: It highlights the elevated relative 
risks of marriage formation for foreign-born women from the former Yugoslavia, North Africa, the Arab Middle East, and Turkey and the depressed relative risks for women from Western Europe. We can also see that many immigrant groups differ very little from the natives with respect to their marriage formation risk.

Table 3a: Relative risk of first marriage formation, by broad country group of origin and other socio-demographic variables. Unmarried women in Sweden, 1983-2007

\begin{tabular}{ll}
\hline Swedish-born parents & 1 \\
Descendant of migrants & $1.08^{\star \star \star}$ \\
One parent Sw-born & $0.92^{\star \star \star}$ \\
Immigrant as child & $1.31^{\star \star \star}$ \\
Immigrant as adult & $0.91^{\star \star \star}$ \\
\hline Primary School & $1.04^{\star \star \star}$ \\
Secondary Education & 1 \\
University & 1.01 \\
\hline Metropolitan & $0.95^{\star \star \star}$ \\
Non-metropolitan & 1 \\
\hline
\end{tabular}

Note: Swedish register data, authors' own calculations. Model includes control for age. ${ }^{\star \star \star}=$ significant at the $1 \%$ level.

Table 3b: Relative risk of first marriage formation, by finer country groups of origin. Unmarried women in Sweden, 1983-2007

\begin{tabular}{ll}
\hline Swedish-born parents & 1 \\
Descendant of migrants & $1.08^{\star \star \star}$ \\
One parent Sw-born & $0.92^{\star \star \star}$ \\
Finland & $0.92^{\star \star \star}$ \\
Other Nordic & $0.82^{\star \star \star}$ \\
Former Yugoslavia & $1.55^{\star \star \star}$ \\
Poland & 0.99 \\
Western Europe & $0.69^{\star \star \star}$ \\
Southern Europe & $0.80^{\star \star \star}$ \\
Baltic & $0.76^{\star \star \star}$ \\
Eastern Europe & $1.04^{\star \star}$ \\
US/Aus/NZ/Can & $0.85^{\star \star \star}$ \\
Central/South America & $0.92^{\star \star \star}$ \\
Horn of Africa & $1.06^{\star \star \star}$ \\
Sub-Saharan Africa & 0.97 \\
North Africa & $1.44^{\star \star \star}$ \\
\hline
\end{tabular}


Table 3b: (Continued)

\begin{tabular}{ll}
\hline Arab Middle East & $2.38^{\star \star \star}$ \\
Iran & $1.12^{\star \star \star}$ \\
Turkey & $2.77^{\star \star \star}$ \\
East Asia & $0.83^{\star \star \star}$ \\
South-East Asia & $0.94^{\star \star \star}$ \\
South Asia & $1.05^{\star \star}$ \\
Post-Soviet States & $0.95^{\star \star}$ \\
\hline
\end{tabular}

Note: Swedish register data, authors' own calculations. Model also includes controls for age, educational attainment and metropolitan/non-metropolitan residence. ${ }^{\star \star \star}=$ significant at the $1 \%$ level, ${ }^{* \star}=5 \%$ level, ${ }^{*}=10 \%$ level.

Table 4 provides additional information in terms of the relative risks of firstmarriage formation for Swedish-born women only, including the descendants of immigrants to Sweden. In this case the country categories represent the birth country of a woman's parents: if only one of her parents is foreign-born she is assigned the category of her foreign-born parent, if both parents are foreign-born but from different origins she is assigned the country group of her mother. The tabulation reveals that Swedish descendants of immigrants from Turkey and the Arab Middle East have elevated marriage formation intensities, very much in line with the patterns observed for their parents. By contrast, when a comparison is made with the parental generation, we note that the marriage risks of the children of immigrants from most European countries, non-European Anglo-Saxon countries, and North Africa are more similar to the marriage risks of the natives. In some other country groups the marriage intensity seems to decrease to relatively low levels and become less similar to that of the natives from one generation to another. This is the case with the descendants of immigrants from Poland, Central/South America, Horn of Africa, Sub-Saharan Africa, Iran, and South East Asia. 
Table 4: Relative risk of first marriage formation for women born in Sweden, by their parents' country group of origin. Never-married women in Sweden, 1983-2007

\begin{tabular}{ll}
\hline Sweden & 1 \\
Finland & $0.93^{\star \star \star}$ \\
Other Nordic & $1.04^{\star \star \star}$ \\
Former Yugoslavia & $1.19^{\star \star \star}$ \\
Poland & $0.86^{\star \star \star}$ \\
Western Europe & $0.97^{\star \star}$ \\
Southern Europe & $0.90^{\star \star \star}$ \\
Baltic & 0.99 \\
Eastern Europe & $0.96^{\star \star}$ \\
US/Aus/NZ/Can & 0.96 \\
Central/South America & $0.80^{\star \star \star}$ \\
Horn of Africa & $0.71^{\star \star \star}$ \\
Sub-Saharan Africa & $0.77^{\star \star \star}$ \\
North Africa & $1.07^{\star}$ \\
Arab Middle East & $1.98^{\star \star \star}$ \\
Iran & $0.80^{\star \star \star}$ \\
Turkey & $2.71^{\star \star \star}$ \\
East Asia & $0.85^{\star \star \star}$ \\
South-East Asia & $0.76^{\star \star \star}$ \\
South Asia & $1.19^{\star \star \star}$ \\
Post-Soviet States & 1.02 \\
\hline
\end{tabular}

Note: Swedish register data, authors' own calculations. Model also includes controls for age, educational attainment, and metropolitan/non-metropolitan residence. ${ }^{\star \star \star}=$ significant at the $1 \%$ level, ${ }^{\star \star}=5 \%$ level, ${ }^{*}=10 \%$ level.

\section{Results II: Divorce risks of immigrants in Sweden}

About 30\% of Swedish-born women had divorced by 15 years after marriage formation. Practically all groups of immigrant women who had formed a marriage in Sweden had higher levels of dissolved marriages (Table 5). Immigrants who arrived in Sweden during childhood had higher divorce rates on average than those who arrived as adults and later married in Sweden. Foreign-born women from Poland and the rest of Eastern Europe, Central \& South America, Iran, South East Asia, and the three regions of Africa had more than $40 \%$ dissolved marriages by 15 years after marriage formation. 
Table 5: Cumulative percentage divorced at durations 5, 10, and 15 years since marriage formation, by country group of origin. First-married women in Sweden, 1983-2007

\begin{tabular}{llll}
\hline & $\mathbf{5}$ & $\mathbf{1 0}$ & $\mathbf{1 5}$ \\
\hline Swedish-born parents & 10 & 20 & 28 \\
Descendant of migrants & 15 & 27 & 37 \\
One parent Sw-born & 14 & 27 & 36 \\
Immigrant as child & 19 & 33 & 42 \\
Immigrant as adult & 15 & 28 & 36 \\
\hline Finland & 15 & 28 & 37 \\
Other Nordic & 14 & 28 & 38 \\
Former Yugoslavia & 16 & 27 & 34 \\
Poland & 22 & 36 & 46 \\
Western Europe & 12 & 23 & 32 \\
Southern Europe & 12 & 22 & 30 \\
Baltic & 14 & 25 & 36 \\
Eastern Europe & 21 & 35 & 44 \\
US/Aus/NZ/Can & 10 & 22 & 31 \\
Central/South America & 25 & 43 & 52 \\
Horn of Africa & 31 & 49 & 58 \\
Sub-Saharan Africa & 25 & 44 & 53 \\
North Africa & 23 & 38 & 45 \\
Arab Middle East & 17 & 28 & 34 \\
Iran & 25 & 41 & 48 \\
Turkey & 13 & 22 & 28 \\
East Asia & 14 & 26 & 34 \\
South-East Asia & 18 & 33 & 41 \\
South Asia & 17 & 31 & 37 \\
Post-Soviet States & 26 & 44 & 55 \\
\hline
\end{tabular}

Note: Swedish register data, authors' own calculations.

The multivariate analyses provide a similar but more concise overview of patterns in divorce risks (Table 6). On average, immigrants and descendants of immigrants have slightly higher divorce risks than native Swedes: the divorce risk for immigrants who arrived in Sweden during childhood is about 25\% higher than for women with two Swedish-born parents (Table 6a). All control variables show strong associations with divorce risks and are important to consider in order to get an accurate picture of how the migration status itself relates to divorce risks. As in our previous presentation, our models for the finer country groups of origin (Table $6 \mathrm{~b}$ ) do not distinguish between migrants who arrived during childhood and those who moved to Sweden as adults. 
Foreign-born women from Poland and other Eastern European countries, Central \& South America, Iran, and the three regions of Africa all have strikingly high divorce risks. By contrast, women from Southern Europe and Turkey have very low divorce risks, substantially lower than that of the Swedish-born population.

Table 6a: Relative risk of divorce, by broad country group of origin and other socio-demographic variables. First-married women in Sweden, 1983-2007

\begin{tabular}{ll}
\hline Swedish-born parents & 1 \\
Descendant of migrants & $1.04^{\star \star}$ \\
One parent Swedish-born & $1.05^{\star \star \star}$ \\
Immigrant as child & $1.26^{\star \star \star}$ \\
Immigrant as adult & $1.09^{\star \star \star}$ \\
\hline Primary School & $1.22^{\star \star \star}$ \\
Secondary Education & 1 \\
University & $0.66^{\star \star \star}$ \\
\hline Metropolitan & $1.23^{\star \star \star}$ \\
Non-metropolitan & 1 \\
\hline Age (Years) & $0.91^{\star \star \star}$ \\
\hline Partner same nationality & $0.76^{\star \star \star}$ \\
\hline
\end{tabular}

Note: Swedish register data, authors' own calculations. Model includes control for duration of marriage. ${ }^{\star \star \star}=$ significant at the $1 \%$ level, ${ }^{\star \star}=5 \%$ level, ${ }^{\star}=10 \%$ level.

Table 6b: Relative risk of divorce, by finer country groups of origin. Firstmarried women in Sweden, 1983-2007

\begin{tabular}{ll}
\hline Swedish-born parents & 1 \\
Descendant of migrants & $1.04^{\star \star}$ \\
One parent Swedish-born & $1.05^{\star \star \star}$ \\
Finland & $1.08^{\star \star \star}$ \\
Other Nordic & $1.07^{\star \star \star}$ \\
Former Yugoslavia & 1.02 \\
Poland & $1.48^{\star \star \star}$ \\
Western Europe & $0.91^{\star \star \star}$ \\
Southern Europe & $0.76^{\star \star \star}$ \\
Baltic & 1.11 \\
Eastern Europe & $1.44^{\star \star \star}$ \\
US/Aus/NZ/Can & $0.91^{\star}$ \\
Central/South America & $1.88^{\star \star \star}$ \\
Horn of Africa & $2.24^{\star \star \star}$ \\
\hline
\end{tabular}


Table 6b: (Continued)

\begin{tabular}{ll}
\hline Sub-Saharan Africa & $1.82^{\star \star \star}$ \\
North Africa & $1.72^{\star \star \star}$ \\
Arab Middle East & $1.12^{\star \star \star}$ \\
Iran & $2.15^{\star \star \star}$ \\
Turkey & $0.69^{\star \star \star}$ \\
East Asia & $1.09^{\star}$ \\
South-East Asia & $1.16^{\star \star \star}$ \\
South Asia & $1.19^{\star \star \star}$ \\
Post-Soviet States & $2.41^{\star \star \star}$ \\
\hline
\end{tabular}

Note: Swedish register data, authors' own calculations. Model also includes controls for duration of marriage, age, educational attainment, partner's country background, and metropolitan/non-metropolitan residence. ${ }^{\star \star \star}=$ significant at the $1 \%$ level, ${ }^{\star \star}=5 \%$ level, ${ }^{*}=10 \%$ level.

\section{Results III: Re-marriage propensities of immigrants in Sweden}

Four in ten first-divorced Swedish native women had re-married at the duration of ten years since marital dissolution (Table 7). Immigrants and their descendants re-marry to a somewhat larger extent than the Swedish-born majority population. Immigrants from the Arab Middle East, Turkey, Iran, North Africa, South Asia, and East Asia have higher re-marriage rates than others.

Table 7: $\quad$ Cumulative percentage re-married at the durations of 5 and 10 years since divorce, by country group of origin. First-divorced women in Sweden, 1983-2007

\begin{tabular}{lll}
\hline & $\mathbf{5}$ & $\mathbf{1 0}$ \\
\hline Swedish-born parents & 23 & 40 \\
Descendant of migrants & 25 & 42 \\
One parent Swedish-born & 24 & 41 \\
Immigrant as child & 29 & 43 \\
Immigrant as adult & 26 & 41 \\
\hline Finland & 23 & 37 \\
Other Nordic & 26 & 42 \\
Former Yugoslavia & 30 & 41 \\
Poland & 28 & 41 \\
Western Europe & 27 & 42 \\
Southern Europe & 24 & 37 \\
Baltic & 28 & 41 \\
\hline
\end{tabular}


Table 7: (Continued)

\begin{tabular}{lll}
\hline & $\mathbf{5}$ & $\mathbf{1 0}$ \\
\hline Eastern Europe & 27 & 42 \\
US/Aus/NZ/Can & 33 & 44 \\
Central/South America & 25 & 40 \\
Horn of Africa & 29 & 43 \\
Sub-Saharan Africa & 30 & 43 \\
North Africa & 35 & 49 \\
Arab Middle East & 42 & 62 \\
Iran & 30 & 48 \\
Turkey & 33 & 49 \\
East Asia & 33 & 51 \\
South-East Asia & 26 & 42 \\
South Asia & 35 & 63 \\
Post-Soviet States & 32 & 47 \\
\hline
\end{tabular}

Note: Swedish register data, authors' own calculations.

The multivariate analyses control for the age distribution of divorcees. They largely confirm the patterns from our univariate analyses: Swedish-born women with one or two foreign-born parents no longer display elevated re-marriage intensities once we bring in our controls (Table 8a). As before, foreign-born women from the Arab Middle East, South Asia, and East Asia have the highest standardized re-marriage rates (Table 8b). Immigrants from overseas Anglo-Saxon countries also display high remarriage risks. We have also experimented with re-marriage models based on all women that divorced in Sweden. This makes the study population larger than in the case when we only study remarriages of people who once entered a first marriage in this country. In the extended study population, remarriage risks become slightly higher for most groups of immigrants but patterns of differences between country groups remain very much the same as those presented below (results available from authors on request). 
Table 8a: Relative risk of re-marriage, by broad country group of origin and other socio-demographic variables. First-divorced women in Sweden, 1983-2007

\begin{tabular}{l|l}
\hline Swedish-born parents & 1 \\
Descendant of migrants & 1.00 \\
One parent Swedish-born & 1.01 \\
Immigrant as child & $1.07^{\star \star \star}$ \\
Immigrant as adult & $1.05^{\star \star}$ \\
\hline Primary School & 0.98 \\
Secondary Education & 1 \\
University & 1.00 \\
\hline Metropolitan & $0.97^{\star \star \star}$ \\
Non-metropolitan & 1 \\
\hline Age (Years) & $0.79^{\star \star \star}$ \\
\hline
\end{tabular}

Note: Swedish register data, authors' own calculations. Model includes control for duration since divorce. ${ }^{\star \star \star}=$ significant at the $1 \%$ level.

Table 8b: Relative risk of re-marriage, by finer country groups of origin. Firstdivorced women in Sweden, 1983-2007

\begin{tabular}{ll}
\hline Swedish-born parents & 1 \\
Descendant of migrants & 1.01 \\
One parent Swedish-born & 1.02 \\
Finland & $0.92^{\star \star \star}$ \\
Other Nordic & $1.09^{\star \star}$ \\
Former Yugoslavia & 1.06 \\
Poland & 0.98 \\
Western Europe & 1.09 \\
Southern Europe & 0.90 \\
Baltic & 1.03 \\
Eastern Europe & 1.05 \\
US/Aus/NZ/Can & $1.31^{\star \star \star}$ \\
Central/South America & 1.01 \\
Horn of Africa & $1.12^{\star}$ \\
Sub-Saharan Africa & $1.22^{\star \star \star}$ \\
North Africa & 1.25 \\
Arab Middle East & $1.76^{\star \star \star}$ \\
Iran & $1.22^{\star \star \star}$ \\
Turkey & $1.24^{\star \star \star}$ \\
\hline
\end{tabular}


Table 8b: (Continued)

\begin{tabular}{ll}
\hline East Asia & $1.39^{\star \star \star}$ \\
South-East Asia & $1.09^{\star}$ \\
South Asia & $1.48^{\star \star \star}$ \\
Post-Soviet States & $1.20^{\star}$ \\
\hline
\end{tabular}

Note: Swedish register data, authors' own calculations. Model also includes controls for duration since divorce, age, educational attainment, and metropolitan/non-metropolitan residence. ${ }^{\star \star \star}=$ significant at the $1 \%$ level, ${ }^{\star \star}=5 \%$ level, ${ }^{*}=10 \%$ level.

\section{Discussion}

In this study we produced a detailed overview of patterns in marriage formation and divorce of immigrant women in Sweden. A key contribution of our study is that we were able to break down the immigrant population into a fairly large number of country categories, representing a wide variety of migrant backgrounds in terms of the societies and family systems they come from. By means of access to large-scale longitudinal register data, we were able to distinguish between and provide statistics for some twenty country groups of immigrant women. In addition, we produced comparable data for the daughters of immigrants in Sweden. A further contribution of our study is that we are able to distinguish between descendant daughters with two foreign-born parents and those with one foreign-born and one Swedish-born parent. We were also able to distinguish between immigrants who arrived in Sweden at adult ages and those who arrived with their parents during childhood.

Unsurprisingly, the heterogeneity of the immigrant population in Sweden also manifests itself in our results. We demonstrated, for example, clear differences between immigrants who arrived to Sweden as adults and those who arrived during childhood. On average, childhood migrants are distinguished by relatively high rates of all civil status transitions: first marriage formation, divorce, and re-marriage. Immigrants who arrived in Sweden unmarried at adult ages have somewhat reduced marriage formation rates and slightly elevated rates of divorce and re-marriage. However, these averages mask clear differences between immigrants depending on their country of origin. We note, for example, that compared to native Swedes, immigrants from Southern Europe have lower risk of all three events analyzed. On the other hand, immigrants from the Horn of Africa, Northern Africa, the Arab Middle East, Iran, and South Asia seem to experience relatively high 'churning rates' of marriage, with elevated levels of first marriage formation as well as high rates of divorce and re-marriage formation. Patterns are less straightforward for other immigrant groups. Interestingly, there is a very weak link between the propensity for first marriage formation and for re-marriage across immigrant groups. 
Our results suggest that the heterogeneity in partnership dynamics across immigrant groups in Sweden is a result of a complex interplay of factors. In our introduction we formulated a few hypotheses regarding mechanisms that will produce different patterns of difference and similarity in the nuptial behavior of migrants. We find at least some evidence of support for each of our four hypotheses. For example, the relatively high levels of divorce for the majority of immigrant groups can likely be ascribed to the disruption of family life that stems from the situation of being a migrant. The stress associated with the migration act and the exposure to new gender and social norms may be responsible for the elevated divorce risks in some groups. The relatively low rates of marriage formation in many country groups of immigrants may also be ascribed to the disruptive effects of migration on partnership formation. However, the act of migration may also affect marriage formation rates in the opposite direction: The elevated risks of first marriage formation for immigrants from Turkey, the Arab Middle East, former Yugoslavia, and North Africa may be related to the common practice of marriage migration in these populations.

In many cases we found patterns in marriage formation and marriage dissolution that were very similar to those observed for the reference group of Swedish-born women with two Swedish-born parents. With some imagination, we could interpret these similarities as evidence of adaptation of behaviors to those prevailing in the Swedish context. However, we also find many differences in behavior that could, also with some imagination, be linked to differences in family systems and patterns in family dynamics in immigrants' countries of origin. The persistence of such differences in behaviors in the Swedish context provides support for the importance of childhood socialization into different modes of family-related behaviors. Family systems differ considerably across countries and regions of the world (cf. Hajnal 1965; Goody 1983; Goode 1963, 1993; Therborn 2004); the cultural and ideational factors linked to these family systems are among the strongest candidates for explaining many group-specific differences in family dynamics. There is very little international comparative data on marriage and divorce that we can rely on in our assessment, ${ }^{6}$ but the demographic and ethnographic literature provides helpful guidance. For example, the literature on Latin America tells of relatively weak families and low levels of formal marriage formation (e.g., López-Gay et al. 2014), while that on Africa tells of often complex and dynamic patterns of marriage formation and marital turnover (e.g., Lesthaeghe, Kaufmann, and Meekers 1989; Tabutin and Schoumaker 2004). The Arab world has historically been characterized by high levels of marital turnover, with high rates of marriage formation,

\footnotetext{
${ }^{6}$ The United Nations provide crude statistics on the estimated fractions of the population in member countries that belong to different civil-status categories and, in some cases, on crude demographic rates of nuptial behavior (e.g., United Nations Statistics Division 2012). However, these statistics are not always very helpful in mapping out patterns of transition into and out of marriage.
} 
divorce, and remarriage (cf. Goode 1993; Cuno 2008), and the same holds for parts of South East Asia (Jones 1997) but not for Iran (Abbasi-Shavazi and McDonald 2008) or Turkey (Nauck and Klaus 2008; Yüksel-Kaptanoğlu, Eryurt, and Koç 2012), where divorce levels traditionally have been low. Our finding on low levels of marriage and divorce for immigrants from Southern Europe aligns very well with familydemographic data from that region (cf. Andersson and Philipov 2002), and that on the elevated remarriage risks of immigrants from overseas Anglo-Saxon countries with US patterns of high marital turnover (Cherlin 2009). In our study the diversity of partnership dynamics is manifested not only in the signs of the coefficients but also in their magnitude. In general, we note that differences in partnership dynamics tend to be more pronounced when natives and non-Western immigrants to Sweden are compared than when the comparison is made with immigrants from more similar countries of origin. In our introduction we argued that the Swedish context provides many elements conducive to reproducing differences in behaviors related to marriage and divorce. In a context where an individual's civil status brings few or no consequences in terms of his or her social rights we may find that cultural and symbolic factors related to marriage play a larger role instead.

Further, the emergence and perpetuation of migration flows to Sweden differ considerably across countries of origin and it is likely that the process of selection into migration shapes our results. To illustrate, Iran and Turkey are neighboring countries which share the same religion and which are placed fairly close to each other on the Inglehart-Weizel cultural map (Inglehart 2006). The two countries do not differ too much with respect to divorce rates at the national level either. If migration from these two countries to Sweden were random one would expect family dynamics to be similar for the two immigrant groups. Yet our results indicate that the risk of first marriage formation is substantially higher among the Turkish-born immigrants in Sweden. Moreover, when looking at divorce risks, these two groups differ from each other more than they differ from Swedish natives. Although we are unable to measure its relative importance, selection into migration is most likely responsible for producing many of the patterns we observe for other groups as well.

We also need to consider how the definition of our study populations relates to the results we observe. For example, as we only follow people who were unmarried upon their arrival in Sweden, we cannot study the marriage and divorce patterns of those who were already married prior to migration or, in the case of marriage migrants, married immediately before registering their migration to Sweden. This likely leads to more evidence of disruption in marriage formation and less evidence of disruption in terms of divorce risks than if we had been able to study the marital trajectories of the married 
migrants as well ${ }^{7}$. Likewise, we experimented with the inclusion of all divorced people in our re-marriage models rather than only studying the initial cohorts of unmarried migrants to Sweden. The approach we chose to present produced somewhat lower remarriage rates, which could be interpreted as more evidence of adaptation in the remarriage careers of the more demographically established immigrants in Sweden.

Our main hypotheses are first of all relevant for the study of actual migrants; some of them may matter for the descendants of immigrants as well. On average, differences are less pronounced between natives and Swedish-born children of immigrants, as far as the first marriage formation is concerned. This is even more pronounced in the case of divorce and re-marriage where the descendants of immigrants only display slightly elevated divorce risks and the same re-marriage risks as those of women with two Swedish-born parents. In the case of first marriage formation we presented a more indepth analysis, by the descendants' parental background. For most European as well as for non-European Anglo-Saxon second generation groups the differences to natives are negligible. This finding is most likely associated with the processes of assimilation and adaptation, at least in the majority of cases in which the relative risk of first marriage formation is depressed in the parental generation but not in the descendant generation. On the other hand, Swedish-born women of Turkish and Arab Middle East parental origin have much higher risk of marriage formation, and they do not differ much from their parents' generation in this sense. This finding suggests that the socialization into group-specific modes of early marriage formation matter for these groups. Interestingly, for many groups, such as children of immigrants from Poland, Central/South America, the Horn of Africa, Sub-Saharan Africa, Iran, and South-East Asia, the differences relative to natives are somewhat more pronounced in the descendant generation. More precisely, while first generation immigrant women from these regions do not differ much from native women, the risk of first marriage formation is substantially lower among the descendants of these immigrants. The finding aligns with findings of depressed fertility in many groups of descendants to immigrants in Sweden (Andersson and Persson 2014). It may indicate different degrees of difficulty for various minority populations in the marriage market and in the process of getting established as a young adult in Sweden.

Our study provided valuable insight into patterns of marriage formation and marriage dissolution of immigrants in Sweden. It addressed many of the research questions we posed but left other issues unaddressed. For example, we leave it for future research to study whether differential levels of first marriage formation and divorce can be ascribed to differences in immigrants' success or lack of success in the

\footnotetext{
${ }^{7}$ It is evident that we cannot study the marriage formation in Sweden of immigrants who were already married at the time of their migration: the lack of data on these migrants' marital duration also hinders us from properly studying their divorce risks.
} 
Swedish labor market. In addition, future research on marriage and divorce in general and on immigrant nuptiality in particular would benefit from paying more attention to the role of men in such dynamics. In the case of marriage formation, it is, for example, sometimes the case that a male migrant moves to a new country while being unmarried, in order to be joined later by his newly wed wife (Statistics Sweden 2015). Such instances of marriage migration go undetected in our study on migrant women.

\section{Acknowledgements}

Our research received funding from the European Union's Seventh Framework Programme (FP7/2007-2013) via the project FamiliesAndSocieties, grant agreement 320116. We are also grateful for financial support from the Swedish Research Council (Vetenskapsrådet) via the Linnaeus Center on Social Policy and Family Dynamics in Europe (SPaDE), grant 349-2007-8701, and the Swedish Initiative for Research on Microdata in the Social and Medical Sciences (SIMSAM), grant 839-2008-7495. Finally, we thank for very helpful comments on earlier versions of our paper from Hill Kulu, Gerda Neyer, Karen Haandrikman, and two anonymous reviewers of Demographic Research. 


\section{References}

Abbasi-Shavazi, M.J. and McDonald, P. (2008). Family change in Iran: Religion, revolution, and the state. In: Jayakody, R. et al. (eds.). International Family Change. New York: Taylor \& Francis: 177-198.

Adsera, A. and Ferrer, A. (2014). Immigrants and demography: Marriage, divorce, and fertility. IZA Discussion Paper, No. 7982.

Andersson, G. (1995). Divorce-risk trends in Sweden 1971-1993. European Journal of Population 11(4): 293-311. doi:10.1007/BF01267721.

Andersson, G. (1997). The impact of children on divorce risks of Swedish women. European Journal of Population 13(2): 109-145. doi:10.1023/A:1005803001 129.

Andersson, G. (1998). Trends in marriage formation in Sweden 1971-1993. European Journal of Population 14(2): 157-178. doi:10.1023/A:1006003520829.

Andersson, G. (2002). Dissolution of unions in Europe: A comparative overview. Zeitschrift für Bevölkerungswissenschaft 27: 493-504.

Andersson, G. (2004a). Childbearing after migration: Fertility patterns of foreign-born women in Sweden. International Migration Review 38(2): 747-775. doi:10.1111/j.1747-7379.2004.tb00216.x.

Andersson, G. (2004b). Children's experience of family disruption and family formation: Evidence from 16 FFS countries. Vienna Yearbook of Population Research 2004: 313-332.

Andersson, G. and Kolk, M. (2011). Trends in childbearing and nuptiality in Sweden: An update with data up to 2007. Finnish Yearbook of Population Research 2011: 21-29.

Andersson, G. and Persson, L. (2014). Childbearing among the descendants of immigrants in Sweden. Stockholm Research Reports in Demography 2014: 17.

Andersson, G. and Philipov, D. (2002). Life-table representations of family dynamics in Sweden, Hungary, and 14 other FFS countries: A project of descriptions of demographic behavior. Demographic Research 7(4): 67-270. doi:10.4054 /DemRes.2002.7.4.

Andersson, G. and Scott, K. (2005). Labour-market status and first-time parenthood: The experience of immigrant women in Sweden, 1981-97. Population Studies 59(1): 21-38. doi:10.1080/0032472052000332683. 
Andersson, G. and Scott, K. (2007). Childbearing dynamics of couples in a universalistic welfare state: The role of labor-market status, country of origin, and gender. Demographic Research 17(30): 897-938. doi:10.4054/DemRes. 2007.17.30.

Bernhardt, E. and Hoem, B. (1985). Cohabitation and social background: Trends observed for Swedish women born between 1936 and 1960. European Journal of Population 1(4): 375-395. doi:10.1007/BF01797149.

Bernhardt, E., Goldscheider, C., Goldscheider, F., and Bjerén, G. (2007). Immigration, Gender and Family Transition to Adulthood in Sweden. Lanham, Md: University Press of America.

Blanc, A. (1987). The formation and dissolution of second unions: Marriage and cohabitation in Sweden and Norway. Journal of Marriage and the Family 49(2): 391-400. doi:10.2307/352308.

Charsley, K. (2005). Unhappy husbands: Masculinity and migration in transnational Pakistani marriages. Journal of the Royal Anthropological Institute 11(1): 85-105. doi:10.1111/j.1467-9655.2005.00227.x.

Cherlin, A. (2009). The Marriage-Go-Round: The State of Marriage and the Family in America Today. New York: Alfred Knopf.

Chiswick, B. (1978). The effect of Americanization on the earnings of foreign-born men. The Journal of Political Economy 86(5): 897-921. doi:10.1086/260717.

Cuno, K. (2008). Divorce and the fate of the family in modern century Egypt. In: Yount, K. and Rashad, H. (eds.). Family in the Middle East. London: Routledge: 196-216.

Darvishpour, M. (2002). Immigrant women challenge the role of men: How the changing power relationship within Iranian families in Sweden intensifies family conflicts after immigration. Journal of Comparative Family Studies 33(2): 271-296.

de Graaf, P. and Kalmijn, M. (2003). Alternative routes in the remarriage market: Competing-risk analyses of union formation after divorce. Social Forces 81(4): 1459-1498. doi:10.1353/sof.2003.0052.

Dewilde, C. and Uunk, W. (2008). Remarriage as a way to overcome the financial consequences of divorce - A test of the economic need hypothesis for European women. European Sociological Review 24(3): 393-407. doi:10.1093/esr/jcn025. 
Dribe, M. and Lundh, C. (2011). Cultural dissimilarity and intermarriage: A longitudinal study of immigrants in Sweden 1990-2005. International Migration Review 45(2): 297-324. doi:10.1111/j.1747-7379.2011.00849.x.

Dribe, M. and Lundh, C. (2012). Intermarriage, value context and union dissolution: Sweden 1990-2005. European Journal of Population 28(2): 139-158. doi:10.1007/s10680-011-9253-y.

Duvander, A.-Z. (1999). The transition from cohabitation to marriage: A longitudinal study of the propensity to marry in Sweden in the early 1990s. Journal of Family Issues 20(5): 698-717. doi:10.1177/019251399020005007.

Eeckhaut, M., Lievens, J., Van de Putte, B., and Lusyne, P. (2011). Partner selection and divorce in ethnic minorities: Distinguishing between two types of ethnic homogamous marriages. International Migration Review 45(2): 269-296. doi:10.1111/j.1747-7379.2011.00848.x.

Furtado, D., Marcén, M., and Sevilla, A. (2013). Does culture affect divorce? Evidence from European immigrants in the United States. Demography 50(3): 1013-1038. doi:10.1007/s13524-012-0180-2.

Goode, W. (1963). World Revolution and Family Patterns. New York: Free Press.

Goode, W. (1993). World Changes in Divorce Patterns. New Haven: Yale University Press.

Goody, J. (1983). The Development of the Family and Marriage in Europe. Cambridge: Cambridge University Press. doi:10.1017/CBO9780511607752.

Graham, M. and Khosravi, S. (1997). Home is where you make it: Repatriation and diaspora culture among Iranians in Sweden. Journal of Refugee Studies 10(2): 115-133. doi:10.1093/jrs/10.2.115.

Haandrikman, K. (2014). Binational marriages in Sweden: Is there an EU effect? Population, Space and Place 20(2): 177-199. doi:10.1002/psp.1770.

Hajnal, J. (1965). European marriage pattern in historical perspective. In: Glass, D.V. and Eversley, D.E.C. (eds.). Population in History. London: Arnold: 101-143.

Hoem, J.M. (1991). To marry, just in case ...: the Swedish widow’s-pension reform and the peak in marriages in December 1989. Acta Sociologica 34: 127-135. doi:10.1177/000169939103400205. 
Huschek, D., Liefbroer, A., and de Valk, H. (2010). Timing of first union among second-generation Turks in Europe: The role of parents, peers and institutional context. Demographic Research 22(16): 473-504. doi:10.4054/DemRes. 2010.22.16.

Inglehart, R. (2006). Mapping global values. Comparative Sociology 5: 114-136. doi:10.1163/156913306778667401.

Jones, G. (1997). Modernization and divorce: Contrasting trends in Islamic Southeast Asia and the West. Population and Development Review 23(1): 95-114. doi:10.2307/2137462.

Kalmijn, M., de Graaf, P., and Janssen, J. (2005). Intermarriage and the risk of divorce in the Netherlands: The effects of differences in religion and in nationality, 1974-94. Population Studies 59(1): 71-85. doi:10.1080/0032472052000332719.

Kelly, M. (2013). Onward Migration: The Transnational Trajectories of Iranians Leaving Sweden [Doctoral Dissertation]. Uppsala: Department of Social and Economic Geography, Uppsala University.

Kulu, H. (2006). Fertility of internal migrants: Comparison between Austria and Poland. Population, Space and Place 12(3): 147-170. doi:10.1002/psp.406.

Kulu, H. and González-Ferrer, A. (2014). Family dynamics among immigrants and their descendants in Europe: Current research and opportunities. European Journal of Population 30: 411-435. doi:10.1007/s10680-014-9322-0.

Lesthaeghe, R., Kaufmann, G., and Meekers, D. (1989). The nuptiality regimes in subSaharan Africa. In: Lesthaeghe, R. (ed.). Reproduction and Social Organization in sub-Saharan Africa. Berkeley: University of California Press: 238-337.

Lesthaeghe, R. and Surkyn, J. (1995). Heterogeneity in social change: Turkish and Moroccan women in Belgium. European Journal of Population 11(1): 1-29. doi:10.1007/BF01264103.

Lewin, F.A. (2001). Identity crisis and integration: The divergent attitudes of Iranian immigrant men and women towards integration into Swedish society. International Migration 39(3): 121-135. doi:10.1111/1468-2435.00159.

López-Gay, A., Esteve, A., López-Colás, J., Permanyer, I., Turu, A., Kennedy, S., Laplante, B., and Lesthaeghe, R. (2014). A geography of unmarried cohabitation in the Americas. Demographic Research 30(59): 1621-1638. doi:10.4054/ DemRes.2014.30.59. 
McDonald, J.T. and Kennedy, S. (2004). Insights into the 'healthy immigrant effect': Health status and health service use of immigrants to Canada. Social Science \& Medicine 59(8): 1613-1627. doi:10.1016/j.socscimed.2004.02.004.

Milewski, N. and Kulu, H. (2014). Mixed marriages in Germany: A high risk of divorce for immigrant-native couples. European Journal of Population 30(1): 89-113. doi:10.1007/s10680-013-9298-1.

Nauck, B. and Klaus, D. (2008). Family change in Turkey: Peasant society, Islam, and the revolution "from above". In: Jayakody, R. et al. (eds.). International Family Change. New York: Taylor \& Francis: 281-312.

Nekby, L. (2012). Cultural integration in Sweden. In: Algan, Y., Bisin, A., Manning, A., and Verdier, T. (eds.). Cultural Integration of Immigrants in Europe. Oxford: Oxford University Press, Studies of Policy Reform: 172-209. doi:10.1093/acprof:oso/9780199660094.003.0006.

Niedomysl, T., Östh, J., and Van Ham, M. (2010). The globalisation of marriage fields: The Swedish case. Journal of Ethnic and Migration Studies 36(7): 1119-1138. doi:10.1080/13691830903488184.

Obućina, O. (2014). Marriage migration and divorce risk in Sweden. Paper presented at the British Society for Population Studies Conference, Winchester, UK. September 2014.

Ohlsson-Wijk, S. (2011). Sweden's marriage revival: An analysis of the newmillennium switch from long-term decline to increasing popularity. Population Studies 65(2): 183-200. doi:10.1080/00324728.2011.574724.

Ohlsson-Wijk, S. (2014). Digit preferences in marriage formation in Sweden: Millennium marriages and birthday peaks. Demographic Research 30(25): 421-432. doi:10.4054/demres.2014.30.25.

Ohlsson-Wijk, S. (2015). Family Formation in Sweden at the Turn of the New Millenium. Stockholm: Stockholm University Demography Unit - Dissertation Series 13.

Parusel, B. (2009). Focus migration: Country profile Sweden. Hamburg: Hamburg Institute of International Economics (HWWI).

Sandström, G. (2011). Time-space trends in Swedish divorce behaviour 1911-1974. Scandinavian Journal of History 36(1): 65-90. doi:10.1080/03468755.2010. 543521. 
Sardon, J.P. (1986). Evolution de la nuptialité et de la divortialité en Europe depuis la fin des années 1960. Population 41(3): 463-482. doi:10.2307/1532803.

Sobotka, T. (2008). The rising importance of migrants for childbearing in Europe. Demographic Research 19(9): 225-248. doi:10.4054/DemRes.2008.19.9.

Statistics Sweden (2004). Efterkrigstidens invandring och utvandring [Immigration and emigration during the postwar period]. Demografiska rapporter 2004:5.

Statistics Sweden (2008). Anhöriginvandrare och deras familjer [Family-reunification immigrants and their families]. Demografiska rapporter 2008:3.

Statistics Sweden (2010). Födda i Sverige - ändå olika? [Born in Sweden - yet different?]. Demografiska rapporter 2010:2.

Statistics Sweden (2012). Sambo, barn, gift, isär? [Cohabiting, kids, married, apart?]. Demografiska rapporter 2012:1.

Statistics Sweden (2014). Generationer genom livet [Generations across life]. Demografiska rapporter 2014:2.

Statistics Sweden (2015). Kärlek över gränserna - migration och familjebildning [Love across the borders - Migration and family formation]. Demografiska rapporter 2015:1.

Tabutin, D. and Schoumaker, B. (2004). The demography of sub-Saharan Africa from the 1950s to the 2000s: A survey of changes and a statistical assessment. Population-E 59(3-4): 457-556. doi:10.2307/3654914.

Therborn, G. (2004). Between Sex and Power. London: Routledge.

Trost, J. (1979). Unmarried Cohabitation. Västerås: International Library.

United Nations Statistics Division (2012). Demographic Yearbook. New York: United Nations.

van de Kaa, D. (1987). Europe’s second demographic transition. Population Bulletin 42.

van Kerckem, K., van der Bracht, K., Stevens, P. and van de Putte, B. (2013). Transnational marriages on the decline: Explaining changing trends in partner choice among Turkish Belgians. International Migration Review 47(4): 1006-1038. doi:10.1111/imre.12053.

Wu, Z. and Schimmele, C. (2005). Repartnering after first union disruption. Journal of Marriage and Family 67(1): 27-36. doi:10.1111/j.0022-2445.2005.00003.x. 
Yüksel-Kaptanoğlu, İ., Eryurt, M.A., and Koç, İ. (2012). Kadınların Evlilik Döngüsü: Evlenme, Boşanma ve Yeniden Evlenme [Marriage cycle of women: Marriage, divorce and remarriage]. Kadın/Woman 2000 13(1): 63-96. 
Andersson, Obućina \& Scott: Marriage and divorce of immigrants and descendants of immigrants in Sweden 